УДК 002.1:008(476):930.25(477)

\title{
Ольга Ямкова
}

Інститут украӥнської археографії та джерелознавства

ім. М. С. Грушевського НАН України,

здобувач

\section{Документальна спадщина діячів білоруської культури в архівах України}

Українські та закордонні дослідники у своїх виступах на наукових конференціях неодноразово акцентували увагу на тому, що в українських архівах зберігається широкий комплекс джерел, які висвітлюють події, пов'язані з суспільно-політичним та культурно-науковим розвитком Білорусі XVI - XX століть, маловідомі факти іiі історії, українсько-білоруські міждержавні зв'язки на початку XX ст., а також особисті документи представників білоруської культури, науки і літератури, доля яких так чи інакше була пов'язана з Україною. I. Матяш, аналізуючи зміст документального комплексу джерел білорусознавчого змісту в українських архівах, зауважила, що він має дві складові: а) періодика; б) архівні документи $[1$, с. 667]. Другий, зокрема, упродовж останніх років активно розробляється українськими та закордонними дослідниками і вже має на сьогодні вагомі здобутки. На основі цього комплексу документальних джерел дослідники опублікували на шпальтах вітчизняних і зарубіжних часописів, збірників документів, матеріалів конференцій низку спеціальних розвідок, монографій, в яких висвітлили широке коло наукових проблем, пов'язаних із історією Білорусі.

Однією із перших в Україні проаналізувала й узагальнила комплекс джерел 3 українських архівів, що місять інформацію про факти, події і особистості, пов'язані з розвитком білоруської державності, культурою, наукою і освітою Білорусі, І. Матяш [1].

Однак, попри інтерес українських науковців до білорусознавчої тематики, значна частина документальних джерел відповідного змісту нині залишається поза увагою українських і зарубіжних науковців. Це також стосується і значної частини документальної спадщини діячів культури, літератури і науки Білорусі, яка відклалася у фондах архівних установ України. 
Метою нашої публікації є спроба охарактеризувати та узагальнити архівну спадщину діячів білоруської культури і науки, яка зберігається в архівних українських установах, з точки зору іiі репрезентативності для дослідження історії українсько-білоруських наукових, літературних та культурних взаємозв'язків XIX ХХ ст.

Зауважимо, що під час підготовки цієї публікації були використані результати власних архівних пошуків та виданий науково-довідковий апарат - анотовані описи фондів чи путівники по фондах, зазначених у публікації українських архівних установ.

Основні документальні комплекси діячів білоруської культури і науки XX ст. зберігаються у фондах Центрального державного архіву вищих органів влади та управління України, Центрального державного архіву-музею літератури і мистецтва України, Центрального державного історичного архіву України (м. Київ) та Центрального державного історичного архіву України (м. Львів), в Інституті рукопису Національної бібліотеки України імені В. І. Вернадського, Відділі рукописів Інституту літератури імені Т. Г. Шевченка НАН України, а також у книжкових, журнальних та газетних фондах Національної бібліотеки України імені В. I. Вернадського, Науково-довідкової бібліотеки центральних державних архівів України. Незначний відсоток документів, пов'язаних 3 цією тематикою, зберігається також у фондах Центрального державного архіву громадських об'єднань України, Державних архівів Волинської, Київської, Чернігівської областей, Державному архіві міста Києва. Здебільшого це документи особового походження: особисті документи, нотатки, автографи поезій, приватні епістолярії та ділове листування, світлини тощо.

У фондах Центрального державного архіву вищих органів влади та управління України (ЦДАВО України) зберігається найбільша 3-поміж інших державних архівів та архівних установ України колекція документів з історії Білорусі XX ст. Документальна спадщина діячів білоруської культури відклалася передусім у фондах так званого Празького архіву ЦДАВО України. Так, у фонді 3859 «Український вільний університет в м. Празі» поміщені родословні (анкети) студентів-білорусів цієї української емігрантської школи - відомих у майбутньому білоруських діячів на культурно-науковій ниві: Л. Красковської, В. Русака, I. Дворчаніна, I. Геніуша та ін. У фонді 3972 «Український високий педагогічний інститут імені М. Драгоманова в м. Празі» зберігаються особові справи студентівбілорусів цього інституту, зокрема: В. Вальтара (спр. 357), Л. Красковської (спр. 557), I. Станкевича (спр. 808) та ін. У цьому ж фонді зберігаються дипломні роботи Л. Красковської «Порівнююча студія візантійської архітектури X - XIII ст. в князівствах Київському, Галицькому, Полоцькому, Суздальському та Новгороді» (1928) (оп. 2, спр. 51) та П. Орси «Рослинні формації Білорусі в зв’ язку з фізичногеографічними типами» (1828) (оп. 2, спр. 81) та ін. документи. 
Важливий комплекс джерел відклався також у фонді 3793 «Український соціологічний інститут в м. Празі». У ньому зосереджені документи, які ілюструють історію створення та діяльність Білоруського наукового кабінету (БНК) як спеціальної наукової установи при Українському інституті громадознавства в Празі: проект статуту та план праці БНК, підготовлені Т. Грибом за дорученням дирекції Інституту (рукопис) (спр. 41). Також у спр. 305 цього фонду віднаходимо списки співробітників Українського соціологічного інституту (б/д), з якого довідуємося, що в цій науковій українській установі в різний час працювали представники білоруської емігрантської громади в Чехословаччині - С. Бусел, Й. Мамонько, Т. Гриб, В. Ластовський, збереглися й особові справи Т. Гриба (спр. 266) та В. Ластовського (спр. 275). Також у цьому фонді зберігається листування БНК з Білоруським науково-дослідним інститутом сільського і лісового господарства в Мінську (1928), Інститутом білоруської культури (Мінськ) (1928). В особистій справі секретаря Білоруського наукового комітету Т. Гриба поміщені копії листів на адресу Інституту білоруської культури в Мінську з подякою за надіслані видання інституту для бібліотеки БНК; Білоруської книжкової палати та Білоруської академії наук з інформаційною довідкою про наукову діяльність БНК, його бібліотеки білорусознавства та архіву, пропозиціями співробітництва та надсилання літератури $(1928,1929)$ (оп. 1, спр.149, 174); копії листів Т. Гриба до М. Вершиніна 3 пропозицією очолити діяльність «...Білоруського національного архіву, який існує при Білоруському науковому кабінеті...» (14 червня 1928 року), Свгена Олександровича [Ляцького] від 4 грудня 1918 року та інших адресатів (оп. 1, спр. 150).

У фонді 4465 «Документи і матеріали українських емігрантських установ, організацій та різних осіб (колекція)» зберігається робота В. Захаріна [В. Захарко] «Білорусія і білорусини», машинопис, 1940 року (спр. 518); замітки В. Трембіцького про географічний, адміністративний устрій населення Білорусії (1942) (спр. 803); підручник А. Смолича «Географія Білорусі», переписаний В. Трембіцьким (1942) (спр. 818) та ін.

У фондах Центрального державного історичного архіву України у м. Львові зберігається незначна кількість документальних джерел, пов'язаних з історією білоруської культури і науки та ії яскравих представників. Так, в особовому фонді Баревича Свгена (ф. 99), адвоката та колекціонера зі Львова зберігається бібліографія праць з історії Білорусії та Литви XVIII - XIX ст., а в особовому фонді Лозинського Владислава (ф. 135), історика культури й мистецтва, письменника збереглися виписки з наукових праць і архівних документів про мистецтво Білорусі в XVII ст. Також необхідно згадати і фонд Івана Крип'якевича (ф. 357), в якому збереглося листування українського історика з білоруським і українським істориком, дослідником українського права Л. Окиншевичем.

Найбільший комплекс джерел особового походження представників білоруської культури зберігається в особових фондах діячів літератури і мистецтва 
України - письменників-прозаїків, поетів, драматургів, публіцистів, перекладачів, критиків, літературознавців, філологів, етнографів, фольклористів Центрального державного архіву-музею літератури і мистецтва України (ЦДАМЛМ України). Аналізуючи комплекс документів цього архіву, необхідно звернути увагу на його надзвичайну репрезентативність і цінність для вивчення історії білоруської літератури другої половини ХХ ст. та українсько-білоруських літературномистецьких зв’ язків цього періоду. Передусім увагу дослідників привертає широкий комплекс епістолярної спадщини білоруських поетів і письменників, яка відклалася в особових фондах архіву-музею. Так, у фондах Ю. Барабаша (ф. 842), О. Корнійчука (ф. 435), Л. Смілянського (ф. 21), В. Сосюри (ф. 44), П. Тичини (ф. 464) та ін. українських письменників і поетів відклалися листи від П. Бровки періоду 1930-х-1970-х рр.; у фондах Г. Бойка (ф. 771), П. Жура (ф. 136), В. Сосюри (ф. 44), Н. Забіли (ф. 702) та ін. - листи від Е. Огнєцвєт, датовані 1965-1967, $1972-$ 1985, 1950, 1952-1977 рр.; листи від Я. Коласа (1935-1952), Я. Купали (1960) зберігаються в особовому фонді П. Тичини та ін. Збереглися також листи від І. Мележа (1954) до А. Головка (ф. 18); М. Танка (1943) до М. Пригари (ф. 242), О. Адамовича (1992) та Я. Бриля (1973) до М. Олійника (ф. 983) та інші епістолярії.

Не менш цінним джерелом (ніж епістолярії) з широкого масиву документів цього архіву є фотографії білоруських і українських поетів та письменників. Так, збереглися фотографії Я. Бриля у товаристві українських поетів і письменників (60-ті - 70-ті рр. XX ст.) (ф. 862); П. Бровки, І. Шамякіна та ін. разом з поетами, письменниками, діячами культури і мистецтва (40-80-ті рр. ХХ ст.) (ф. 25, ф. 779, ф. 1041, ф. 1110, ф. 1126). У фонді українського письменника Ю. Збанацького (ф. 663) зберігаються його фотографії в товаристві П. Бровки, К. Крапиви, М. Танка, I. Шамякіна та ін., датовані 40-80-ті pp. XX ст., а у фонді іншого українського письменника - О. Підсухи - збереглися його фото з М. Танком (ф. 957) та ін.

Також у фондах архіву-музею зберігаються переклади поезій білоруських поетів на українську та російську мови: у фондах М. Бажана (ф. 535), П. Жура (ф. 136), А. Малишка (ф. 22), А. Шмигельського (ф. 906) та ін. - переклади поезій П. Бровки; у фонді Ф. Ісаєва (ф. 1015) - переклади з білоруської на українську мову творів С. Гаврусьова, К. Кирієнка, А. Кулешова, Ю. Свірки (1955-1970); у фондах А. Малишка, А. Шмигельського та ін. - переклади творів М. Танка 19431949, 1960-х рр. та ін. Особовий фонд Феофана Скляра (ф. 987), українського перекладача і поета-сатирика, цікавий для дослідників передусім його перекладами українською мовою з білоруської казки Ф. Богушевича «Хтивий і скарб на Івана Купала» (1950-і), поетичних творів П. Бровки, Я. Коласа, А. Кулешова, Я. Купали, Е. Огнєцвєт (1960-i), I. Сіпакова та М. Танка (1970-і).

3-поміж широкого масиву документів архіву-музею необхідно згадати і про наукові публікації українських літературознавців, письменників і літературних критиків, присвячені постатям білоруських поетів і письменників. Зокрема, ціка- 
вими для сучасних дослідників можуть бути: статті М. Бажана про А. Кулешова (1964) та П. Бровку (1965) (ф. 535); Л. Коваленка про Я. Купалу («Янка Купала и украинская литература» (1982)) (ф. 878); нарис Т. Масенка «Рідний Янка Купала» та його ж спогади про поїздку до Білорусі в 60-70-тих рр. ХХ ст. (ф. 479) та ін.

Серед інших документів, які висвітлюють творчу діяльність білоруських майстрів слова, в особових фондах цього архіву віднаходимо численні рецензії на їх прозові та поетичні твори, а $з$ документів особового походження - дарчі написи, вітальні листівки, нотатки тощо.

Завершуючи короткий огляд документального масиву білорусознавчого змісту ЦДАМЛМ України варто звернути увагу на цікаві й інформативні документальні джерела фондів національних літературно-мистецьких установ. Зокрема, у фонді Національної спілки письменників України і Центрального Будинку літератора поміщені стенограми спільного з письменниками Білорусі та Росії засідання секретаріату (1980-і рр.), документи про проведення тижня письменників Білорусі в Україні (1950-і - 1960-і рр.) (ф. 590); у фонді Національної спілки театральних діячів України збереглися документи про підготовку і проведення Днів літератури і мистецтва України в Білорусі (1976) (ф. 616), а 3-поміж документів фонду «Національний академічний драматичний театр ім. Івана Франка»є почесні грамоти та подяки театру за гастрольні поїздки від колективів Білоруської РСР (ф. 570).

Стаття В. Пірадова, диригента, народного артиста Казахської РСР та УРСР, про роботу Білоруського театру опери та балету (1949) поміщена в його особовому фонді (ф. 158).

Додаткове значення для вивчення проблематики, пов'язаної з історією білоруської культури, літератури і мистецтва мають документальні джерела фондів місцевих Державних архівних установ. Зокрема, у фондах «Ніжинський юридичний ліцей князя I. Безбородька, м. Ніжин Чернігівської губ.» (ф. 1359) та «Окружний суд, м. Чернігів» (ф. 249) Державного архіву Чернігівської області зберігаються: документи студента юридичного ліцею Ф. Богушевича та «Особова справа судового слідчого - білоруського поета, того ж таки Ф. Богушевича».

3-поміж документів фонду «Волинський обласний комітет ЛКСМУ, м. Луцьк (1939-1941, 1944-1991)» Державного архіву Волинської області привертають увагу фотоальбоми про перебування на Волині делегації Білоруської РСР під час Днів літератури і мистецтва Білорусії на Україні (б/д).

Аналізуючи комплекс документальних джерел, прямо чи опосередковано пов'язаних з представниками білоруської культури, варто звернути увагу на особові фонди представників різних, переважно гуманітарних, галузей науки і культури України, які зберігаються в архівних установах Національної академії наук України: Інституті рукопису Національної бібліотеки України імені В. І. Вернадського та Відділі рукописів Інституту літератури імені Т. Г. Шевченка НАН України. 
Так, зокрема в особовому фонді Інституту рукопису Національної бібліотеки України імені В. І. Вернадського (IP НБУВ) історика й археолога Василя Юхимовича Данилевича зберігаються його лекції і програми до них з історії Великого князівства Литовського (1907-1908) та історії Білорусі (1936). Серед широкої епістолярної спадщини українського науковця виявлено лист до В. Данилевича від В. Ластовського, датований 23 червня 1929 року Вацлав Юстинович у той час працював на посаді директора Білоруського державного музею і в епістолярній формі консультувався зі своїм українським колегою в справі ідентифікації загадкової мідної печатки ймовірно XVII ст. (ф. XXIX).

В особовому фонді Миколи Павловича Дашкевича збереглася його стаття під назвою «Борьба культур и народност[ей] в Литов[ско]-русском государстве в период династи[ческой] унии Литвы с Польшей», датована 1844 роком (ф. 65).

Особовий фонд історика і педагога Михайла Івановича Лілєєва містить його авторські наукові праці «История раскольников Стародуба, Ветки и других раскольничьих слобод на Украине в XVII-XX вв.» [кін. XIX ст.], «О передаче в Археографическую комиссию архивных дел о раскольниках» (б/д) та ін. (ф. 127).

Необхідно звернути увагу на зміст ще двох особових фондів цієї архівної установи: Федора Івановича Титова та Павла Івановича Тиховського. Перший був відомим істориком церкви, книгознавцем, вивчав історію релігійних рухів, у тому числі й у Білорусі. Саме тому в його фонді відклалися унікальні колекційні матеріали: документи про духівництво, семінарії, церковні справи в Білорусі та Литві (1728-1908) (оригінали і копії); листи Віленської комісії для розбору й видання давніх актів (1911, 1914), Мінського кафедрального собору (1902) та інші документи (ф. 175).

У фонді П. Тиховського, українського фольклориста і педагога, зберігається рідкісне і раритетне на сьогоднішній день видання «Учительские книги Ветхого завета в переводе Скорины» (б/д) (ф. 197).

Необхідно зауважити, що в особових фондах українських літературознавців і поетів, які зберігаються в цій архівній установі, є також переклади на українську мову творів білоруських поетів та прозаїків. Так, в особовому фонді письменника i журналіста М. Шудрі відклалися переклади з білоруської мови поезій М. Богдановича «Межі» (1963), В. Дубовки «Васильки збирала» та ін. (1964) (ф. 229). В особовому фонді Г. Литвака, українського літератора, поета і перекладача, збереглися переклади білоруських народних пісень на російську мову, а також збірка казок «Золотое перо. Советские сказки народов СССР», укладена ним у 1950 році (ф. 25).

Завершуючи короткий огляд комплексу документів білорусознавчого змісту 3 фондів ІР НБУВ, доцільно насамкінець зупинитися на великому за об' ємом фонді «Академії наук УРСР» (ф. Х), який вміщує широкий масив джерел з історії Білорусі, українсько-білоруських наукових взаємин та співпраці науковців України і Білорусі. 
Варто привернути увагу дослідників до декількох документів, виявлених автором цієї публікації з-поміж матеріалів цього фонду. Зокрема, це лист М. М. Щекочихина, білоруського мистецтвознавця, історика і відомого педагога до В. І. Барвінка, співробітника Академії наук УРСР, історика, дослідника історії слов’янських народів та українського стародрукарства. Згаданий лист датовано 18 червня 1929 року. Микола Миколайович інформує свого українського колегу про наукові та мистецькі заходи в Білорусі, приурочені до відзначення ювілею 400-ліття білоруського друку. Зокрема, він перелічує наукові публікації та окремі видання, присвячені цій визначній події, які були опубліковані в тогочасних наукових білоруських часописах та за кордоном: власні авторські публікації, статті М. В. Довнар-Запольського, 3. Жилуновича «Эвалюцыя беларускай кніжкі», М. Шаповалова «Ф. Скарына, яго дні ды друк на Беларусі» (Мінськ, 1925) та інші (ф. Х, спр. 34662).

Другий документ - це фрагмент листа відомого білоруського національного діяча, історика О. Цвікевича до українського історика, державного діяча М. Грушевського. На жаль, перший чи перші аркуші цього листа не збереглися. Проте, проаналізувавши зміст уцілілого фрагмента, вважаємо, що безпосередньо О. Цвікевич ініціював відновлення контактів з українським вченим, спробував налагодити постійні листовні контакти між ними. Доречно нагадати, що особисте знайомство білоруського і українського державних діячів відбулося ще у квітні 1918 року, коли О. Цвікевич на чолі делегації Народного Секретаріату БНР прибув до української столиці для участі в переговорах з представниками Центральної Ради, головою якої був М. Грушевський. У частині листа, яка збереглася, не вказана дата його написання, проте зі змісту можемо припустити, що написаний він між 1927 і 1928 роками, оскільки на час написання листа О. Цвікевич працював на посаді вченого секретаря в Інституті білоруської культури в Мінську, а з 1929 року - в Інституті історії Білоруської академії наук. М. Грушевський на той час уже був обраний академіком Всеукраїнської академії наук, очолював історикофілологічний відділ та археографічну комісію ВУАН. Уцілілий фрагмент цього листа для ознайомлення з його змістом білоруських і українських дослідників подаємо у додатку.

Великий масив документів, пов’язаних з історією білоруської культури, літератури й мистецтва, відклався також у фондах Відділу рукописів Інституту літератури імені Т.Г. Шевченка НАН України. Документи білорусознавчого змісту зберігаються переважно у фондах особового походження та колекціях документів, присвячених творчій діяльності українських письменників та поетів.

Переклади українською мовою з білоруської творів М. Богдановича (1918, 1919, б/д) вміщені у фонді М. Драй-Хмари (ф. 198); поезій П. Бровки, П. Глєбки, А. Кулешова (1953, 1956, б/д) - у фонді Л. Первомайського (І. Гуревича) (ф. 133). У фонді українського радянського поета і громадського діяча М. Рильського збе- 
рігаються його переклади українською мовою з білоруської літературних творів Ф. Богушевича «Горе» (1950), «Удова» (1950); П. Глєбки «Покликав нас батько до бою...», машинопис (б/д); Я. Коласа «Ворогам» (б/д), «Лісам Білорусії» (1946), «Радянським народам» (1953), «Ти - неначе прекрасна весна...» (1953), «Янку Купалі» (б/д); К. Кропиви «Піп та папуга» (1949); А. Кулешова «Соняшник», машинопис (1946); Я. Купали «А хто там іде?» (б/д), «Весна по весні» (б/д), «Над річкою Оресою», переклад частини поеми (б/д), «Пісня і сила» (б/д), «Про Сталінасіяча», машинопис (б/д), «Рідне слово» (1946); Е. Самуйльонка «Мисливське щастя» (б/д); М. Танка «Вогні Мінська» (б/д) (ф. 137). Переклад російською мовою 3 білоруської п’єси К. Кропиви «Дружба», автограф перекладача та машинопис 3 виправленнями К. Крапиви (1930-і рр.) зберігається у фонді П. Зенкевича (ф. 148).

Серед архівних матеріалів особового фонду М. Рильського віднаходимо також його статті: «Богданович Максим Адамович» (1959), «Письмо Петрусю Бровке» (б/д), «Про Якуба Коласа» (1952), «Про Янку Купалу» (1952), «Янка Купала» (1952); рецензію М. Рильського на книгу «Антологія білоруської радянської поезії в українських перекладах»; нотатки записів «Подорож по Білорусії» (1958); а також листи М. Рильського до П. Глєбки (1950), А. Кулешова (б/д) та листи, адресовані М. Рильському від Я. Бриля (1958-1963, б/д), П. Бровки (1947-1964, б/д), А. Кулешова (1961-1964, б/д), М. Танка (1953-1964).

Епістолярна спадщина білоруських поетів і письменників відклалася також в інших фондах цієї архівної установи. Зокрема, фотокопія листа Я. Купали до директора Будинку-музею Т. Г. Шевченка (1940) зберігається у фонді «Матеріали письменників народів колишнього СРСР» (ф. 140), а лист А. Кулешова до А. Малишка, датований 1943 роком - у фонді «Матеріали письменників-учасників Великої Вітчизняної війни 1941-1945 рр.» (ф. 57). Епістолярії білоруських поетів і письменників, адресовані українським колегам на літературній ниві, зберігаються також у фонді «Матеріали письменників української новітньої літератури» (ф. 75). Це, зокрема, листи: Я. Коласа до М. Полотая (1952); Я. Бриля - до Ю. Мартича (1965-1966); Я. Купали до Т. Масенка (1937-1938) з поясненнями до них Т. Масенка.

Серед інших важливих і цікавих матеріалів із фондів Відділу рукописів доцільно згадати і про фотодокументи. Зокрема, у фонді «Матеріали діячів культури та мистецтва України» (ф. 74) відклалося фото, датоване 1940 роком, на якому зображені українські та білоруські поети і письменники В. Василевська, К. Студинський, Я. Колас, Ф. Пестряк, Я. Купала, М. Линьков, М. Возняк; фото делегатів Всесоюзної конференції пролетарських письменників (делегати від Білорусі Ц. Гартний, М. Чарот, Весьолий) зберігається у згаданому вище ф. 75.

Особливе місце 3-поміж центрів зберігання матеріалів білорусознавчого змісту в Україні займає Науково-довідкова бібліотека центральних державних архівів України (НДБ ЦДА України) у м. Києві. У книжковому фонді цієї бібліотеки збе-

Енциклопедичний вісник України. Випуск 1, 2009. 
рігаються рідкісні та унікальні білоруські видання 1920-х - 1930-х рр. Зокрема, це такі наукові, публіцистичні та художні твори громадсько-політичних діячів і поетів Білорусі: «Білоруське відродження» М. Богдановича в перекладі на українську мову (Відень, 1916); «Кароткая гісторыя Беларусі» Власта (В. Ластовського) (Вільня, 1910); «Белорусский вопрос к моменту Версальской мирной конференции. Историко-политический очерк» І. Варонко (Ковна, 1919); збірник документів «Белоруссы и поляки. Документы и факты из исторіи оккупаціи Белоруссіи поляками в 1918 и 1919 годах» (Ковна, 1919), укладений К. Єзовітовим; науковополітичні праці О. Цвікевича «Адраджэньне Беларусі і Польшча» (Менск-ВільняБерлін, 1921), «Беларусь. Политический очерк» (Берлин, 1919) та його ж критичнопубліцистична розвідка «Пагляд П. Безсонава на беларускую справу» (Ковна, 1922); поетична поема «Тарас-Палясоушчык» - видання ковенського товариства імені Ф. Скорини (Коўна, 1920); агітаційно-політична брошура «Зямлі беларускаму сялянству!» під криптонімом «Я.С.» (Несьвіж, 1921) та ін.

У журнальному та газетному фондах бібліотеки зберігаються не менш рідкісні на сьогодні білоруські часописи та газети, які видавалися у 1920-х роках. Це окремі числа таких журналів і газет: «Крывіч», який редагувався К. ДужДушевським і В. Ластовським і видавався в Ковно (1923, 1924), «Беларускі студэнт» (Прага, 1923), «Беларускі дзень» (Вільно, 1927), «Беларусская хроника» (Вильно, 1927), «Беларусское слово» (Вильно, 1927), «Беларускі радны» (Вільно, 1928), «Золак: орган маладой беларускай сацыялістычнай думкі» (Вільно, 1933, 1936), а також «Бюлетэнь загранічнай групы беларускай партыі сацыялістаўрэвалюцыянэраў», який видавався у Празі в 1925-1928 pp. і на шпальтах якого вміщені не лише програмні матеріали цієї партії і статті відомих білоруських емігрантських діячів, але й інформаційні повідомлення та хроніка 3 життя міжвоєнної білоруської еміграції в Чехословаччині.

Картографічний фонд містить мапи білоруських міст: Бобруйська, Могильова, Мозиря, Гомеля, датовані 1918 роком, а також комплекти мап Віленської, Гродненської, Мінської та Могильовської губерній 1912-1919 та 1915-1917 років.

Отже, зважаючи на активний розвиток упродовж останніх років білорусознавства в Україні, науковий інтерес як українських, так і закордонних дослідників до документальних джерел білорусознавчого змісту в архівах України виникла необхідність створення реєстру та видання міжархівного покажчика фондів українських архівних установ, в яких відклалися документи з історії, літератури, культури й науки Білорусі.

\section{ЛІТЕРАТУРА}

1. Матяш І. Б. Джерела до історії Білорусі в XX ст. в українських архівах // Białoruś w XX stuleciu w kręgu kultury i polityki / Pod red. D. Michluk. - Toruń, 2007. - s. 667-683. 
2. Центральний державний історичний архів України, м. Львів: Путівник / Автори-упоряд.: О. Гнєвишева, У. Сдлінська, Д. Пельц, Г. Сварник, І. Сварник, Н. Франко. - К., 2001. - 412 с.

3. Центральний державний архів-музей літератури і мистецтва України: Путівник / Автори-упоряд.: М. Крячок, С. Кущ, 3. Сендик. - К., 2003. - Вип. 1. $486 \mathrm{c}$.

4. Центральний державний архів-музей літератури і мистецтва України: Путівник / Автори-упоряд.: Ю. Кулініч, С. Кущ, М. Ходоровський. - К., 2004. Вип. 2. -622 с.

5. Державний архів Волинської області: Анотований реєстр описів фондів органів і організацій Компартії України (1939-1991) / Автор. колектив: В. Гика, I. Вронська, Н. Бондарук та ін. - Луцьк, 2006. - 788 с.

6. Особові архівні фонди Інституту рукопису: Путівник / Автор. колектив: О. Боляк, С. Булатова, Т. Воронкова, С. Даневич та ін. - К., 2002. - 768 с.

7. Путівник по фондах відділу рукописів Інституту літератури / Г. Бурлака (заг. ред.), В. Бурбела (підгот.). - К., 1999. - 863 с.

\section{Додаток}

...мо М. П. Погодіну (выд. 1871 г. СПБ) - есьць заметка аб тым, што у яго, Максімовіча, быў у 1838 г. партрэт Даніловіча. «Я жил тогда (піша Максімовіч) в бывшем на Печерске доме Семенюты. Смотрю (пад час зеляўздрыгу) на стене у меня закачался, как маятник, портрет приснопамятного проф. И. Н. Даниловича».

Дзе цяпер гэты партрэт? Кіяўляне павінны аб гэтым ведаць. Ці не загінуў ен, - а можа дзе небуд[зь] пераданы у музэй? Будзьце ласкавы, дарагі Міхайла Сяргеевіч, - даведайцеся ў якога спэцыялістага аб гэтай важнай для мяне справе.

Я знайшоў партрэты Даніловіча толькі ў двох журналах - у Тыгодніку Ільлюстраваным (польскім) і ў «Энцыклопэды Повшэхнэй». Але гэта даволі дрэнна зробляныя адбіткі. Вось была бы радасьць, - дастаць запраўдны партрэт майго гэроя!..

Я працую ў Інбелкульце - кірую Камісіяй па гісторыі асьветы на Беларусі. Можна мне адказаць на адрас Інбелкульту, - а лепш да хаты: Менск, вул. Энгельса, 41. Аляксандру Іван. Цьвікевічу.

Вяртаюсь яшчэ да «гуртка». Есьць сьведчаньні што ен быццым быў у сувязі 3 славянскім таварыствам на Валыні, якое была ў сваю чаргу зьвязана з Обществом Южных Славян. У кніжцы «Повстання декабристів на Україні» - я знайшоў нататкі аб Валынскім таварыстве, - але нічога аб якой небудзь сувязі, ня толькі рэвалюцыйнай, але навуковай, ці якой іншай з Вільняй, ці наогул з «Літвой» - там няма. 
Можа сярод украінскіх гісторыкаў хто небудз[ь] гэтым бліжэй цікавіцца? Добра было, каб Вы мяне з гэткай асобай хоць бы лістоўна пазнаемілі.

3 нецярплівасьцю буду чакаць Вашага адказу, - спадзяюся, што хоць што небудзь ад Вашых навуковых багатых ведаў скарыстаю,

3 глыбокай пашанай

А. Цьвікевіч

ІР НБУВ. - Ф. Х. - Спр. 18770. - Арк. 1. Машинопис. 